\title{
Assessment of Food Security, Anthropometric and Cognitive Function among Orang Asli Children in Pahang, Malaysia
}

Teh S.C. ${ }^{a}$, Asma', $^{\text {A }}{ }^{a}$, Hamid Jan, J.M. $^{b}$,Yusof, H.M. ${ }^{a}$

${ }^{a}$ Faculty of Fisheries and Food Science, Universiti Malaysia Terengganu, 21030 Kuala Nerus, Malaysia

${ }^{\text {bS }}$ chool of Health Sciences, Universiti Sains Malaysia, 16150 Kubang Kerian, Kelantan, Malaysia

\section{ABSTRACT}

Introduction: Forest clearing for agriculture plantations and local community settlements may trigger food insecurity, which causes poor development, predominantly in Orang Asli children. This cross-sectional study was conducted to determine the relationships between food security and anthropometric and cognitive function among Orang Asli children in Temerloh, Pahang. Materials and methods: A total of one hundred and sixty-seven children (ages 7 to 11) from five selected Orang Asli villages (Kampung Sungai Enggang, Kampung Penderas, Kampung Pasu, Kampung Lubok Wong, and Kampung Pian) were involved in this study. The food security index was assessed using the Radimer/Cornell Hunger and Food Insecurity Instrument. Anthropometric indices were based on height-for-age and BMI-for-age Z-scores, while cognitive performance was tested using Raven's Coloured Progressive Matrices (R-CPM). Results: A majority (91.6\%) of the respondents reported some kind of food insecurity $(12.6 \%$ household food insecure, $74.2 \%$ individual food insecure, and $4.8 \%$ child hunger). Rates of stunting, thinness, and overweight/obesity were $25.8 \%, 16.2 \%$, and $18.0 \%$, respectively. A majority $(46.1 \%)$ of the children had average cognitive scores, followed by below average $(38.3 \%)$ and above average $(15.6 \%)$, respectively. Height-for-age was significantly associated with cognitive function $(p=0.008)$. Among sociodemographic factors, household size $(p=0.007)$ and household income $(p<0.05)$ were significantly associated with the food security index, whereas the educational status of the child was significantly associated with height-for-age $(p=0.013)$ and cognitive function $(p=0.003)$. Conclusion: Food insecurity remains a risk factor for child development impairment in the Orang Asli community. Undernutrition remains a major health concern among respondents; however, no association was found between food security index and cognitive function.

KEYWORDS: Orang Asli children, food security, undernutrition, cognitive function

\section{INTRODUCTION}

The Orang Asli, the indigenous people of Peninsular Malaysia, live in peripheral communities under impoverished conditions, and lack basic amenities. ${ }^{1}$ The total population of Orang Asli in Malaysia is estimated to be 210,000 people, ${ }^{2}$ with the highest population in Pahang state at 67,506 people. $^{3}$ Regardless of their progress in terms of economic development and continual efforts by the government, they are still afflicted by poverty and their health is persistently lagging behind. ${ }^{4}$

Corresponding Author:

Assoc. Prof. Dr. Hayati Mohd Yusof

Faculty of Fisheries and Food Science,

Universiti Malaysia Terengganu,

21030 Kuala Nerus, Malaysia

Telephone: +609-6684961

Email: hayatimy@umt.edu.my
The Krau Wildlife Reserve consists of natural forests for the purpose of biodiversity conservation mainly within the District of Temerloh, Pahang. However, $14.5 \%$ and $26.7 \%$ of the land has been cleared for agriculture plantations and local community settlements, respectively. ${ }^{5}$ Decreasing forest reserves for hunting and gathering among Orang Asli communities and the transition from traditional subsistence agriculture to cash crop farming has altered their sources of food supply and diet composition, subsequently, lower the nutritional quality of diet which causes poor growth and development predominantly in children ${ }^{6}$. Also, Pahang has remarkably higher percentages of moderately underweight children at $3.8 \%$, particularly due to significant populations of indigenous people in rural areas. ${ }^{7}$ Therefore, anthropometric data and tracking trends in growth 
and development are important, as these reflect children's general health status and dietary adequacy. $^{8}$

The poverty rate among the Orang Asli was 34\% in 2014. ${ }^{9}$ Poverty is considered a risk factor for food insecurity, as it causes lower quantity and quality of food consumption. ${ }^{10}$ This consequently increases the likelihood of poor mental, social, and pyschoemotional growth. ${ }^{11}$ Previous studies have reported that more than $80 \%$ of the households among Orang Asli in Selangor, Malaysia are food insecure. ${ }^{12-13}$ Besides, most Orang Asli children are underweight and stunted, 4, 6, 14-16 indicating that undernutrition remains a serious concern. However, the food security index of the Orang Asli in Temerloh, Pahang remains unknown. In general, food security means that all people, at all times, have physical and economic access to sufficient, safe, and nutritious food to meet their dietary needs and food preferences in an active and healthy life. ${ }^{17}$

The few extant studies on the cognitive function of Orang Asli school children in rural Malaysia have reported that a majority of Orang Asli children have the low cognitive ability, ${ }^{4,18}$ which is influenced by household income and maternal education. ${ }^{4}$ Additionally, household food insecurity is a negative and potent stressor that can increase levels of anxiety, stress, and depression among children's caregivers, in turn affecting the optimal development of children. ${ }^{19}$ However, no study has investigated the association between food security index towards the cognitive function among Orang Asli children in Malaysia. Therefore, this research is aimed to determine levels of food security and the anthropometric and cognitive functioning of Orang Asli children in Temerloh.

\section{MATERIALS AND METHODS}

\section{Subject recruitment}

This was a cross-sectional study over two months from July 2017 to August 2017, involving 167 Orang Asli children aged 7 to 11 years old in the district of Temerloh, Pahang. The selected Orang Asli settlements were Kampung Sungai Enggang, with the nearby primary school Sekolah Rendah Bolok, Kampung Penderas, Kampung Pasu, Kampung Lubok Wong, and Kampung Pian, which is situated near Sekolah Rendah Penderas. It is observed that the
Orang Asli villages involved are surrounded by agricultural crops such as rubber trees and oil palm.

\section{Research instruments}

An interviewer-administered questionnaire was used in this study which consisted of four sections: sociodemographic information, food security index, anthropometric measurements, and cognitive function test. Assessment of the food security index involved ten questions of Radimer/Cornell Hunger and Food Insecurity Instrument ${ }^{20}$ that had been translated into the Malay language, while anthropometric measurements such as weight, height, BMI-for-age Z-score ${ }^{21}$, and height-for-age $\mathrm{Z}$ score. ${ }^{21-22}$ The cognitive function test included 36 questions of diagrammatic puzzles of Raven's Coloured Progressive Matrices (R-CPM). ${ }^{23}$

\section{Data collection}

Before data collection, all 'Tok Batin' (village leaders) and representatives from the related five Orang Asli settlements were informed about the research. The parents of the subjects were verbally briefed about the study and approved consent form. Face-to-face interviews were conducted with mothers or female guardians only to obtain detailed information on socio-demographic characteristics and Radimer/Cornell Hunger and Food Insecurity Instrument. For the anthropometric measurements, body weight was recorded to the nearest $0.1 \mathrm{~kg}$ using a weighing scale (Tanita, Japan), whereas height was measured to the nearest $0.1 \mathrm{~cm}$ using a measuring tape. For the cognitive function test, one student at a time was administered the R-CPM (Pearson Education Inc., London) in a quiet, distraction-free environment. The ages of the children in completed years were confirmed by their parents.

\section{Data analysis}

To classify the severity of food insecurity, ${ }^{20}$ food security was reflected by negative answers to all hunger and food insecurity items. A household was considered to be insecure when positive answers were given to one or more items (items 1 to 4 ), but not to individual or child level items. Next, individual insecurity was present if positive answers were given to one or more items (items 5 to 8 ), but not to items 9 and 10 . Child hunger was determined 
to exist with positive answers to items 9 and 10 . Negative answers were "not true", whereas positive answers included "sometimes true" or "often true". Households with individual food insecure also experienced household food insecurity, whereas households with child hunger also face household food insecurity and individual food insecurity.

The Z-score of Orang Asli children were determined using age- and sex-specific cut-off points of standard graphs. ${ }^{21-22}$ Meanwhile, a correct answer for each question of R-CPM answer was given a score of one, whereas a wrong answer was given zero. Thus, raw scores for the R-CPM test range between zero and 36. Standardized table ${ }^{23}$ was used to transfer the total raw score to the standard score with qualitative descriptions.

Statistical Package for the Social Sciences programme version 20.0 was used for data analysis. In all analyses, $\mathrm{p}<0.05$ was used to indicate significant outcomes.

\section{Research approvals}

Permission to conduct the study was obtained from the Department of Aboriginal Affairs, Malaysia [JAKOA/PP.30.032Jld39(52)], Ministry of Education Malaysia [KPM.600-3/2/3Jld48(23)], Department of Education Pahang, Malaysia [JPNP.SPS.UPP.600-2/6/ Jld.12(13)] and Department of Education Temerloh, Pahang [PPDT.600-4/5/9(30)]. Ethical approval was received from the Research Management and Innovation Centre, Universiti Malaysia Terengganu [UMT/RMIC/2-2/62(38)].

\section{RESULTS AND DISCUSSION}

\section{Demographic profile}

Table 1 shows the distribution of respondents according to socio-demographic characteristics. Among 167 respondents, 53.9\% were boys and $46.1 \%$ were girls, with only $4.2 \%$ of them not attending school. Jahut $(82.0 \%)$ were the largest group. The median of the number of children in a household and household size were four and six, respectively.
More mothers (35.3\%) were illiterate as compared to their fathers. Most of the fathers (91.0\%) were working, and about half of the mothers (54.5\%) were housewives. A majority (57.5\%) of the respondents were categorized as hardcore poor $(\leq \mathrm{RM} 460) .{ }^{24}$

Table 1: Socio-demographic characteristics of respondents

.

Gender

$$
\text { Characteristics }
$$$$
\mathrm{n}=167
$$

(n)

(n)

(\%)

$\begin{array}{lll}\text { Boy } & 90 & 53.9 \\ \text { Girl } & 77 & 46.1\end{array}$

Age of child (years old)

$\begin{array}{lcc}7 & 15 & 9.0 \\ 8 & 28 & 16.8 \\ 9 & 27 & 16.2 \\ 10 & 43 & 25.7 \\ 11 & 54 & 32.3\end{array}$

Median (lqR): 10 (3)

Educational status $\begin{array}{lll}\text { Not attending school } & 7 & 4.2\end{array}$ $\begin{array}{lll}\text { Attending school } & 160 & 95.8\end{array}$

Tribes

$\begin{array}{lcc}\text { Che Wong } & 17 & 10.2 \\ \text { Temuan } & 8 & 4.8 \\ \text { Jahut } & 137 & 82.0 \\ \text { Jakun } & 4 & 2.4 \\ \text { Semai } & 1 & 0.6\end{array}$

Number of children

$\begin{array}{ccc}1-3 & 83 & 49.7 \\ 4-6 & 64 & 38.3 \\ 7-9 & 15 & 9.0 \\ \geq 10 & 5 & 3.0\end{array}$

Range: $1-12$

Median (IqR): 4 (3)

Household size

$\begin{array}{ccc}1-3 & 6 & 3.6 \\ 4-6 & 80 & 47.9 \\ 7-9 & 51 & 30.5 \\ \geq 10 & 30 & 18.0\end{array}$

Range: $3-15$

Median (lqR): 6 (3)

Educational level of father

$\begin{array}{lll}\text { Not attending school } & 44 & 26.3 \\ \text { Primary school } & 61 & 36.5 \\ \text { Secondary school } & 51 & 30.5\end{array}$

Educational level of mother

$\begin{array}{lll}\text { Not attending school } & 59 & 35.3 \\ \text { Primary school } & 68 & 40.7 \\ \text { Secondary school } & 40 & 24.0\end{array}$


Con't

Employment status of father

$\begin{array}{lcc}\text { Working } & 152 & 91.0 \\ \text { Not working } & 4 & 2.4\end{array}$

Employment status of mother

$\begin{array}{lll}\text { Working } & 76 & 45.5 \\ \text { Housewife } & 91 & 54.5\end{array}$

Household income

$\begin{array}{lcc}\text { Hardcore poor" }(\leq \mathrm{RM} 460) & 96 & 57.5 \\ \text { Poor }^{\text {" }}(\leq \mathrm{RM} 760) & 40 & 24.0 \\ \text { Low income }^{\text {I }}(\leq \mathrm{RM} 2000) & 28 & 16.8 \\ \text { Middle income }(>\mathrm{RM} 2000) & 3 & 1.8\end{array}$

"Government Transformation Programme 22 ; IqR= Interquartile Range

Food security index, anthropometric indices, and cognitive function

A majority (91.6\%) of the respondents reported food insecurity, with $12.6 \%$ household insecure, $74.2 \%$ individual insecure, and $4.8 \%$ experiencing child hunger. Most of the children had normal growth for BMI-for-age at $65.8 \%$ and height-for-age at $74.2 \%$. A majority $(46.1 \%)$ of the children had an average cognitive level, followed by below average (38.3\%) and above average (15.6\%) respectively (Table 2 ).

The prevalence of food insecurity in this study (91.6\%) was slightly higher than the previous study among Orang Asli in Selangor at the range of 82 $88 \% .^{12-13}$ Incidences of individual food insecurity were more common, while household food insecurity and child hunger were lower than those reported in the previous studies. ${ }^{12-13}$ The results indicate that food insecurity among Orang Asli in Temerloh, Pahang is worse than in Selangor. One reason could be advancing forest clearing for agricultural plantations, causing difficulty in hunting and gathering ${ }^{6}$, which in turn affects their food resources and food security index. The respondents had to compromise with the quantity and quality of foods available in the household, and mothers were tempted to reduce their food consumption so that their children had enough food to eat. ${ }^{20,25}$ Thus, the prevalence of individual food insecurity is higher and child hunger is lower among Orang Asli children in Temerloh. It is also interesting to note that another study reported several factors responsible for household food insecurity, including agricultural failure, unproductive traditional food hunting methods, and issues related to water and weather, which serve as important distinctions for Asli household food security as compared to the general population. ${ }^{26}$

In this study, the prevalence of thinness or severe thinness was $16.2 \%$, while stunting or severe stunting was $25.8 \%$. This result is in contrast to the previous studies, in which rates of thinness and stunting among Orang Asli children in Krau Wildlife Reserve (KWR), Pahang, were $11.9 \%$ and $64.2 \%$, respectively. ${ }^{14}$ Although there have been improvements in the nutritional status among Orang Asli children, undernutrition remains a major health concern due to the impoverished environment.

Table 2: Food security index, anthropometric indices and cognitive function of respondents

\begin{tabular}{|c|c|c|}
\hline \multirow[t]{2}{*}{ Variable } & \multicolumn{2}{|c|}{$n=167$} \\
\hline & (n) & $(\%)$ \\
\hline \multicolumn{3}{|l|}{ Food Security Index } \\
\hline Food secure & 14 & 8.4 \\
\hline Household insecure & 21 & 12.6 \\
\hline Individual insecure & 124 & 74.2 \\
\hline Child hunger & 8 & 4.8 \\
\hline \multicolumn{3}{|l|}{ BMI-for-age } \\
\hline Severe thinness & 4 & 2.4 \\
\hline Thinness & 23 & 13.8 \\
\hline Normal & 110 & 65.8 \\
\hline Overweight & 19 & 11.4 \\
\hline Obesity & 11 & 6.6 \\
\hline \multicolumn{3}{|l|}{ Height-for-age } \\
\hline Severe stunted & 6 & 3.6 \\
\hline Stunted & 37 & 22.2 \\
\hline Normal & 124 & 74.2 \\
\hline \multicolumn{3}{|l|}{ Cognitive Level $^{\mathrm{a}}$} \\
\hline Extremely low $(<70)$ & 12 & 7.2 \\
\hline Borderline $(70-80)$ & 17 & 10.2 \\
\hline Low average (80-90) & 35 & 20.9 \\
\hline Average $(90-110)$ & 77 & 46.1 \\
\hline High average (110-120) & 22 & 13.2 \\
\hline Superior $(120-130)$ & 4 & 2.4 \\
\hline
\end{tabular}

${ }^{a}$ Cognitive level categorised based on standard scores ${ }^{21}$

Twenty years ago, the prevalence of overweight children in rural areas of Malaysia was about $1 \% .{ }^{27}$ Furthermore, $5.2 \%{ }^{14}$ of the Orang Asli children were overweight or obese in 2015, and this incidence further increased in the present study to $18 \%$. Studies showed that Orang Asli has poor diet quality with little variety, and tend to depend on comparatively inexpensive processed foods, which are poorly nutrient-dense, high in saturated fat and sugar but low in fibre, that can be purchased at nearby shops or town. ${ }^{6,28-29}$ This may lead to overweight or obesity. Therefore, childhood obesity is a rising nutritional concern among the Orang Asli population. 
In the present study, $38.3 \%$ of the respondents had a below-average cognitive level, which is contradictory with previous studies in which the majority (67.6\%) of the Orang Asli school children in Pos Betau, Pahang were in the category of poor cognitive function. ${ }^{4}$ The increasing cognitive levels among Orang Asli children might be due to government efforts in introducing special education programmes for both indigenous children and parents such as a special curriculum, K9 comprehensive model school, and Adult Class for Indigenous Parents. $^{7}$

The low cognitive ability among Orang Asli children may be due to a lack of well-equipped schools, proficient teachers, and adequate infrastructure in rural areas. ${ }^{4}$ However, based on observation, both primary schools are provided with complete facilities including a computer laboratory, library, and science laboratories. Thus, there may be other factors that cause poor cognitive achievement among Orang Asli children, such as poor socioeconomic status, parasitic infections, malnutrition, micronutrients deficiency, ${ }^{30-32}$ diet insufficiency, non-delivery of educational assistance, culture difference, prenatal and postnatal practices, as well as undedicated caregiver personalities. $^{33-35}$

There were no associations between the food security index and anthropometric indices and cognitive function. However, only height-for-age zscore was significantly associated with cognitive function (Table 3), but there was no significance between BMI-for-age z-score and cognitive performance (data not shown).

No significant association between food security index towards anthropometric indices was found, which is in line with a previous study that found no significant differences in children's nutritional status according to the household food security levels among pre-schoolers from low-income households in Kuala Lumpur. ${ }^{36}$ This may be explained by several factors. First, the mothers who participated in this study may not have reported the actual situation of their household food security, as they may have misunderstood the question related to the quality of diet due to lack of nutritional knowledge. Second, anthropometric measurements in this study may not be sensitive enough to assess nutritional status over a short period of time. Perhaps biochemical and clinical assessments such as a urinalysis, blood haemoglobin, total protein, and albumin may be more applicable to determine the health consequences of food insecurity. Third, the aetiology of malnutrition is very complex, as it may be influenced by other risk factors such as diet insufficiency (diet quality and quantity), recurrent infections, birth weight, socioeconomic and health status. $^{13,36}$ In other words, food insecurity can, but not necessarily cause in malnutrition.

A non-significant association $(p>0.05)$ between food security index and cognitive function was supported by a study among American school-aged children. ${ }^{37}$ This might be due to developmental complications that do not rely on single causes, where an increasing number of risk factors could lead to poorer scores, including food insecurity, environmental, past nutrition, health, and social risks. ${ }^{4,30-32}$ Additionally, the insignificant association between food security index and cognitive performance in this study might be due to the overall assessment of food inadequacy without specifically considering the impact of individual macronutrients and micronutrients deficiencies on cognitive achievement. Previous reviews have stated that early cognitive development can be influenced by a few nutrients related to specific physiological processes, including omega-3 fatty acids, vitamin B12, folic acid, choline, iron, iodine, and zinc. ${ }^{38-39}$ However, the results of intervention trials by using single micronutrients are inconclusive; thus, betterdesigned intervention trials are needed that take the interactive effects of nutrients into account. ${ }^{38}$

A significant relationship between cognitive scores and height-for-age z-scores has been shown in previous studies. ${ }^{40-42}$ In rural areas of Southern Ethiopia, poor cognitive performance of children was related to stunting and severely reduced by malnutrition, in which one unit increase in heightfor-age might increase the child's visual processing and short-term memory scores by 1.2 and 1.9 units, respectively. ${ }^{40}$ This indicated long-term malnutrition has a significant impact on the overall cognitive development of children. Meanwhile, among Southeast Asian (Indonesia, Malaysia, Thailand, and Vietnam) school-aged children, low height-for-age zscore doubles the chance of having below-average cognitive scores. ${ }^{41}$ The potential explanation could be a low height-for-age z-score particularly stunting reflects long-term undernutrition. The relationship 
between undernourishment and cognitive abilities is often multi-factorial in origin, consisting of a combination of factors such as protein-energy malnutrition, micronutrient deficiencies, and chronic and recurrent infections that likely contributes to impaired cognitive development in children. ${ }^{43}$ Besides, protein-energy malnutrition is the most prevalent cause of stunting. ${ }^{44}$ Previous studies have shown that protein deprivation negatively affects brain development. ${ }^{45}$ Direct biochemical changes in the central nervous system can influence a child's ability to learn, ${ }^{46}$ and therefore affect cognition outcomes.

According to a study among children in the United States, BMI was negatively related to cognition, as a higher BMI was related to poorer cognitive performance. ${ }^{47-48}$ Elevated BMI may inhibit neural network activation ${ }^{47}$ and increase the severity of obstructive sleep apnea. ${ }^{48}$ In contrast, the present study has found no significant association between BMI-for-age and cognition of children. BMI-for-age acts as a measure of recent nutritional assessment which changes dramatically in the height-weight relationship during growth and development in school age. $^{41}$ Hence, BMI may underestimate the relationship between weight status and childhood cognitive performance. Additionally, the BMI of the respondents in this study represents only "normal" and "not normal" due to insufficient sample size for thinness and overweight or obese children among participated respondents. This might constrain the significance of the association between categories of $\mathrm{BMI}$ and cognitive level.
Children who attended school tends to achieve normal height-for-age (73.1\%) and average cognitive score $(54.6 \%)$. This shows that height-for-age may indirectly affect cognitive development. The significant relationship between the educational status of children towards cognitive performance can be further explained by the study among the children in rural north-western China, in which a one -year delay in school entry reduces children's cognitive ability scores by 0.11 to 0.16 standard deviations. ${ }^{49}$ Thus, school enrolment is significantly related to children's cognitive development, as lateschool-entry may be harmful to cognitive growth.

Association between socio-demographic factors towards food security index, anthropometric indices, and cognitive function

There was a significant association between the educational status of child and height-for-age $(p=0.013)$ (Table 3$)$ and cognitive function $(p=0.003)$ (data are not shown). Children attending school tended to reach normal height-for-age $(73.1 \%)$ and average cognitive scores (54.6\%). Household size was significantly associated with the food security index $(p=0.007)$ (Table 4). Due to insufficient food-secure households, the data were analysed according to the categories of household income. Significant associations were found between hardcore poor and poor households towards food security $(p=0.008)$, hardcore poor and low-income households towards food security $(p=0.023)$, and hardcore poor and middle-income households towards food security $(p=0.007)$, as shown in Table 4 .

Table 3: Association between socio-demographic factors and height-for-age among Orang Asli children ( $n=167)$

\begin{tabular}{|c|c|c|c|c|}
\hline \multirow[t]{2}{*}{ Factors } & \multicolumn{2}{|c|}{ Height-for-age } & \multirow[t]{2}{*}{$\chi^{2}(\mathrm{~d} f)$} & \multirow[t]{2}{*}{$\mathrm{p}$ value } \\
\hline & $\begin{array}{l}\text { Normal } \\
(n=124)\end{array}$ & $\begin{array}{c}\text { Stunted / } \\
\text { Severely } \\
\text { stunted } \\
(n=43)\end{array}$ & & \\
\hline & n (\%) & n (\%) & & \\
\hline Educational Status of Child ${ }^{a}$ & & & - & $0.013^{*}$ \\
\hline Attending school & $122(73.1 \%)$ & $38(22.8 \%)$ & & \\
\hline Not attending school & $2(1.2 \%)$ & $5(3.0 \%)$ & & \\
\hline \multicolumn{5}{|l|}{ Cognitive Level $^{\mathrm{b}}$} \\
\hline Extremely low & $4(2.4 \%)$ & $8(4.8 \%)$ & $11.716(3)$ & $0.008^{*}$ \\
\hline $\begin{array}{l}\text { Borderline/ low } \\
\text { average }\end{array}$ & $\begin{array}{l}40(24.0 \%) \\
61(36.5 \%)\end{array}$ & $\begin{array}{l}12(7.2 \%) \\
16(9.6 \%)\end{array}$ & & \\
\hline High/ superior & $19(9.4 \%)$ & 7 (4.2\%) & & \\
\hline
\end{tabular}

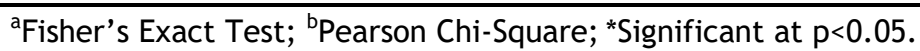


Table 4: Association between socio-demographic factors and food security index of Orang Asli children $(n=167)$

\begin{tabular}{|c|c|c|c|c|}
\hline Factors & $\begin{array}{l}\text { Food } \\
\text { Secure } \\
(n=14)\end{array}$ & $\begin{array}{c}\text { Food } \\
\text { Insecure } \\
(n=153)\end{array}$ & $\chi^{2}(\mathrm{~d} f)$ & $\mathrm{p}$ value \\
\hline & n (\%) & n (\%) & & \\
\hline Educational Status of Child ${ }^{\mathrm{a}}$ & & & - & 1.000 \\
\hline Attending school & $14(8.4 \%)$ & $146(87.4 \%)$ & & \\
\hline Not attending school & $0(0 \%)$ & 7 (4.2\%) & & \\
\hline Tribes $^{a}$ & & & - & 0.066 \\
\hline Senoi & $11(6.6 \%)$ & $144(86.2 \%)$ & & \\
\hline Proto-Malay & $3(1.8 \%)$ & $9(5.4 \%)$ & & \\
\hline Number of Children ${ }^{a}$ & & & - & 0.223 \\
\hline $1-6$ & $14(8.4 \%)$ & $133(79.6 \%)$ & & \\
\hline$>6$ & $0(0 \%)$ & $20(12.0 \%)$ & & \\
\hline Household Size $^{\mathrm{b}}$ & & & $7.163(1)$ & $0.007^{*}$ \\
\hline $1-6$ & $12(7.2 \%)$ & $74(44.3 \%)$ & & \\
\hline$>6$ & $2(1.2 \%)$ & $79(47.3 \%)$ & & \\
\hline Educational Level of Father ${ }^{a}$ & & & - & 0.758 \\
\hline Attending school & $11(7.1 \%)$ & $101(64.7 \%)$ & & \\
\hline Not attending school & $3(1.9 \%)$ & $41(26.3 \%)$ & & \\
\hline Educational Level of Mother ${ }^{a}$ & & & - & 0.142 \\
\hline Attending school & $12(7.2 \%)$ & $96(57.5 \%)$ & & \\
\hline Not attending school & $2(1.2 \%)$ & 57 (34.1\%) & & \\
\hline Employment Status of Father ${ }^{a}$ & & & - & 0.316 \\
\hline Working & $13(8.3 \%)$ & $139(89.1 \%)$ & & \\
\hline Not working & $1(0.6 \%)$ & $3(1.9 \%)$ & & \\
\hline Employment Status of Mother ${ }^{b}$ & & & $0.834(1)$ & 0.361 \\
\hline Working & $8(4.8 \%)$ & 68 (40.7\%) & & \\
\hline Housewife & $6(3.6 \%)$ & 85 (50.9\%) & & \\
\hline \multicolumn{5}{|l|}{ Household Income $^{\mathrm{a}}$} \\
\hline $\begin{array}{l}\text { Harcore poor" } \\
(<R M 460)\end{array}$ & $2(1.2 \%)$ & $94(56.3 \%)$ & & \\
\hline $\begin{array}{l}\text { Poor } \\
(\leq \mathrm{RM} 760)\end{array}$ & $6(3.6 \%)$ & $34(20.4 \%)$ & - & $0.008^{*},{ }^{1}$ \\
\hline $\begin{array}{l}\text { Low income } \\
(\leq \mathrm{RM} 2000)\end{array}$ & $4(2.4 \%)$ & $24(14.4 \%)$ & - & $0.023^{*}{ }^{2}$ \\
\hline $\begin{array}{l}\text { Middle income } \\
(>\mathrm{RM} 2000)\end{array}$ & $2(1.2 \%)$ & $1(0.6 \%)$ & - & $0.007^{*},^{3}$ \\
\hline
\end{tabular}

${ }^{a}$ Fisher's Exact Test; ${ }^{b}$ Pearson Chi-Square; *Significant at $\mathrm{p}<0.05$; ${ }^{1}$ Significant between hardcore poor and poor; ${ }^{2}$ Significant between hardcore poor and low income; 'Significant between hardcore poor and middle income; "Government Transformation Programme (PEMANDU, 2011); Senoi=Che Wong, Jahut and Semai; ProtoMalay=Temuan and Jakun

The significant association between household size and food security index among Orang Asli children $(\mathrm{p}=0.007)$ was comparable to previous studies on Orang Asli households $s^{12-13}$ and low-income communities in Malaysia. ${ }^{50-52}$ It has been reported that as household size increases, food-insecure households reach approximately 80 to $90 \%$ of total expenditures on housing, utilities, and food, as compared to food-secure households at 60 to $70 \% .{ }^{50}$
Therefore, due to limits on resources and widespread sharing among household members, the consumption of food was inadequate and might contribute to food insecurity.

Household income being significantly associated with food security index was in line with the previous studies in Malaysia. ${ }^{10,12-13,51-53}$ A study among the rural community in Bachok Kelantan reported that 
households with better income opportunities had a reduced likelihood of becoming food insecure, as an increase RM10 in the household income will decrease the odds of being food insecure by $3 \% .^{51}$ In a previous study, the poverty line was reported as less than RM691, whereas the present study categorized subjects as hardcore poor or poor if their incomes were less than RM460 or RM760, respectively. Both locations are surrounded by agriculture plantations. In Bachok, subjects worked on tobacco farms, whereas in Temerloh, they worked on rubber and palm oil estates. Another recent study on Orang Asli children in Negeri Sembilan found that the father's education level and income were associated with cognitive function. ${ }^{54}$ In their study, the Wechsler Preschool and Primary Scale of Intelligence, Fourth Edition (WPPPSI-IV) was used instead of R-CPM. Future studies should be carried out to determine how different tools used might affect the outcomes, apart from considering differences in data categorization. Generally, insufficient income among poor households could reduce the ability to obtain adequate food for family members.

\section{CONCLUSION}

Food insecurity is still a major public health problem, while the prevalence of child hunger is low among Orang Asli children in Temerloh. Furthermore, their cognitive functioning has improved, which might be due to the governments' strong efforts in introducing special education programs for both parents and children. The present study concluded that socioeconomic status significantly influenced food security. Intervention programs should be designed to improve the food security index, which in turn will promote healthy growth and development among Orang Asli children.

\section{CONFLICT OF INTEREST}

The authors declare no conflicts of interest. Financial support was obtained from the School of Food Science and Technology, Universiti Malaysia Terengganu, Malaysia.

\section{ACKNOWLEDGMENTS}

The authors would like to thank all participants involved in this study and gratefully acknowledge every party who approved to conduct this research.

\section{REFERENCES}

1. Renganathan S. Educating the Orang Asli children: exploring indigenous children's practices and experiences in schools. The Journal of Educational Research 2016; 109(3): 275-285.

2. Jabatan Kemajuan Orang Asli Malaysia (JAKOA). Laporan Tahunan JAKOA 2014. Kuala Lumpur 2014: 126p.

3. Jabatan Kemajuan Orang Asli Malaysia (JAKOA). Bilangan kampung dan penduduk Orang Asli mengikut negeri 2012. [online]. Available at: http://www.data.gov.my/data/ ms_MY/dataset/jabatan-kemajuan-orang-aslijakoa-488/resource/b6cf4e5d-ada9-4461-8344 -dd296726cfa0. Accessed March 20, 2017.

4. Al-Mekhlafi HM, Mahdy MA, Sallam AA, Ariffin WA, Al-Mekhlafi AM, Amran AA, Surin J. Nutritional and socio-economic determinants of cognitive function and educational achievement of aboriginal schoolchildren in rural Malaysia. British Journal of Nutrition 2011; 106: 1100-1106.

5. Perhilitan. Krau Wildlife Reserve Management Plan for 2002-2006. Kuala Lumpur 2001: 136p.

6. Chua E, Zalilah M, Chin Y, Norhasmah S. Dietary diversity is associated with nutritional status of orang asli children in Krau Wildlife Reserve, Pahang. Malaysian Journal of Nutrition 2012; 18(1): 1-13.

7. United Nations Malaysia. Malaysia Millennium Development Goals Report 2015. Kuala Lumpur 2015: 229p.

8. National Health and Nutrition Examination Survey (NHANES). Anthropometry procedures manual. Centers for Disease Control and Prevention. 2007: 1-6.

9. Economic Planning Unit (EPU). Strategy paper 2: elevating b40 households towards a middleclass society. Eleventh Malaysia Plan 20162020. Putrajaya 2015: 23p.

10. Mohamadpour M, Zalilah MS, Keysami AM. Food insecurity, health and nutritional status among sample of palm-plantation households in Malaysia. Journal of Health, Population and Nutrition 2012; 30(3): 291-302.

11. Pérez-Escamilla R. Food security and the 2015 -2030 sustainable development goals: from human to planetary health. Current Developments in Nutrition 2017; 1: 1-8.

12. Nurfahilin T, Norhasmah S. Factors and coping strategies related to food insecurity and nutri- 
tional status among Orang Asli women in Malaysia. International Journal of Public Health and Clinical Sciences 2015; 2(2): 55-66.

13. Zalilah MS and Tham BL. Food security and child nutritional status among Orang Asli (Temuan) households in Hulu Langat, Selangor. Medical Journal of Malaysia 2002; 57(1): 36-50.

14. Wong CY, Zalilah MS, Chua EY, Norhasmah S, Chin YS, Siti Nur'Asyura A. Double-burden of malnutrition among the indigenous peoples (Orang Asli) of Peninsular Malaysia. BMC Public Health 2015; 15: 680-688.

15. Wong WK, Foo PC, Roze MNM, Pim CD, Subramaniam $\mathrm{P}$, Lim BH. Helminthic infection and nutritional studies among Orang Asli children in Sekolah Kebangsaan Pos Legap, Perak. Canadian Journal of Infectious Diseases and Medical Microbiology 2016: 1-5.

16. Al-Mekhlafi MSH, Surin J, Atiya AS, Ariffin WA, Mahdy AKM, Abdullah HC. Current prevalence and predictors of protein-energy malnutrition among schoolchildren in rural Peninsular Malaysia. Southeast Asian Journal of Tropical Medicine and Public Health 2008; 39(5): 922931.

17. The state of food security and nutrition in the world. Food and Agriculture Organization of the United Nations (FAO). 2017. Rome: FAO. $117 \mathrm{p}$.

18. Zaleha MI, Iskandar ZA, Khalid AK, Osman A. Effect of iodized oil supplementation on thyroid hormone levels and mental performance among Orang Asli schoolchildren and pregnant mothers in an endemic goitre area in Peninsular Malaysia. Asia Pacific Journal of Clinical Nutrition 2000; 9(4): 274-281.

19. Perez-Escamilla R, Pinheiro de Toledo Vianna R. Food insecurity and the behavioral and intellectual development of children: a review of the evidence. Journal of Applied Research on Children: Informing Policy for Children at Risk 2012; 3(1): Article 9.

20. Radimer KL, Olson CM, Campbell CC. Development of indicators to assess hunger. Journal of Nutrition 1990; 120: 1544-1548.

21. World Health Organization (WHO). Growth reference 5-19 Years. 2007. Available at: http://www.who.int/growthref/en/ (accessed 11 April 2017).

22. World Health Organization (WHO). Training course on child growth assessment: WHO child growth standards. Geneva 2008: 48p.

23. Raven J. Coloured progressive matrices and crichton vocabulary scale manual. London: Pearson Education, Inc. 2008: 98p.

24. Performance Management and Delivery Unit (PEMANDU). Government Transformation Programme: Annual Report 2011. Putrajaya 2011: 330p.

25. Radimer KL, Olson CM, Greene JC, Campbell CC, Habicht JP. Understanding hunger and developing indicators to assess it in women and children. Journal of Nutrition Education 1992; 24(1): 36S-44S.

26. Murtaza SF, Gan WY, Sulaiman N, Shariff ZM, Ismail SIF. Sociodemographic, nutritional, and environmental factors are associated with cognitive performance among Orang Asli children in Malaysia. PLoS ONE 2019;14(7): e0219841

27. Khor GL, Taib MNM, Kandiah M, Hashim JK, Hashim JK, Nor SM, Don R. Appraising the current food and nitrition situation with policy implications. Malaysian Journal of Nutrition 1998; 4: 91-106.

28. Haemamalar K, Zalilah MS, Neng AA. Nutritional status of Orang Asli (Che Wong tribe) adults in Krau Wildlife Reserve, Pahang. Malaysian Journal of Nutrition 2010; 16(1): 5568.

29. Nurfaizah S, Zalilah MS, Khor GL, Mirnalini K, Nawalyah AG, Hejar AR. Food variety score is associated with dual burden of malnutrition in Orang Asli (Malaysian indigenous peoples) households: implications for health promotion. Asia Pacific Journal of Clinical Nutrition 2009; 18(3): 412-422.

30. Poh BK, Lee ST, Yeo GS, Tang KC, Noor Afifah AR, Siti Hanisa A, Parikh P, Wong JE, Ng ALO. Low socioeconomic status and severe obesity are linked to poor cognitive performance in Malaysian children. BMC Public Health 2019; 19(Suppl 4): 541.

31. Prado EL, Dewey KG. Nutrition and brain development in early life. Nutrition Reviews 2014; 72(4): 267-284.

32. Hamid Jan JM, Amal MK, Hasmiza H, Pim CD, $\mathrm{Ng}$ LO, Wan MWM. Effect of gender and nutritional status on academic achievement and cognitive function among primary school children in a rural district in Malaysia. Malaysian Journal of Nutrition 2011; 17(2): 189-200.

33. Nurliyana AR, Zalilah MS, Mohd Taib MN, Gan 
WY, Tan KA. Early growth and home environment are associated with cognitive development in the first year of life of Malaysian infants. Early Human Development 2020; 140.

34. Dotti Sani GM, Treas J. Educational gradients in parent's child-care time across countries, 1965-2012. Journal of Marriage and Family 2016; 78(4): 1083-1096.

35. Crosnoe R, Leventhal T, Wirth RJ, Pierce KM, Pianta RC. Family socioeconomic status and consistent environmental stimulation in early childhood. Child Dev. 2010; 81(3): 972-987.

36. Zalilah MS, Ang M. Assessment of food insecurity among low income households in Kuala Lumpur using the Radimer/ Cornell food insecurity instrument - a validation study. Malaysian Journal of Nutrition 2001; 7(1\&2): 15-32.

37. Alaimo K, Olson CM, Frongillo EA. Food insufficiency and American school-aged children's cognitive, academic, and psychosocial development. Pediatrics 2001; 108(1): 44-53.

38. Nyaradi A, Li J, Hickling S, Foster J, Oddy WH. The role of nutrition in children's neurocognitive development, from pregnancy through childhood. Frontiers in Human Neuroscience 2013; 7(97): 1-16.

39. Black MM. Micronutrient deficiencies and cognitive functioning. The Journal of Nutrition 2003; 133: 3927S-3931S.

40. Bogale A, Stoecker BJ, Kennedy T, Hubbs-Tait $L$, Thomas D, Abebe $Y$, Hambidge KM. Nutritional status and cognitive performance of mother-child pairs in Sidama, Southern Ethiopia. Maternal and Child Nutrition 2011; 9(2): 274-284.

41. Sandjaja, Poh BK, Rojroonwasinkul N, Nyugen BKL, Budiman B, Ng LO, Soonthorndhada K, Xuyen HT, Deurenberg P, Parikh P. Relationship between anthropometric indicators and cognitive performance in Southeast Asian school-aged children. Brititsh Journal of Nutrition 2013; 110: S57-S64.

42. Tarleton JL, Haque R, Mondal D, Shu J, Farr BM, Petri WA. Cognitive effects of diarrhea, malnutrition, and entamoeba histolytica infection on school age children in Dhaka, Bangladesh. The American Journal of Tropical Medicine and Hygiene 2006; 74(3): 475-481.

43. Rosenberg M. Global child health: burden of disease, achievements, and future challenges. Current Problems in Pediatric and Adolescent Health Care 2007; 37: 338-362.
44. He Z, Sun Z, Liu S, Zhang Q, Tan Z. Effects of early malnutrition on mental system, metabolic syndrome, immunity and the gastrointestinal tract. Journal of Veterinary Medical Science 2009; 71(9): 1143-1150.

45. Diaz-Cintra S, Cintra L, Ortega A, Kemper T, Morgane PJ. Effects of protein deprivation on pyramidal cells of the visual cortex in rats of three age groups. The Journal of Comparative Neurology 1990; 292: 117-126.

46. Hall A, Khanh LNB, Son TH, Dung NQ, Lansdown RG, Dat DT, Hanh NT, Moestue H, Khoi $\mathrm{HH}$, Bundy DAP. An association between chronic undernutrition and educational test scores in Vietnamese children. European Journal of Clinical Nutrition 2001; 55: 801-804.

47. Kamijo K, Khan NA, Pontifex MB, Scudder MR, Drollette ES, Raine LB, Evans EM, Castelli DM, Hillman $\mathrm{CH}$. The relation of adiposity to cognitive control and scholastic achievement in preadolescent children. Obesity 2012; 20: 2406-2411.

48. Li Y, Dai Q, Jackson JC, Zhang J. Overweight Is associated with decreased cognitive functioning among school-age children and adolescents. Obesity 2008; 16(8): 1809-1815.

49. Chen $\mathrm{Q}$. Impacts of late school entry on children's cognitive development in rural northwestern China-does preprimary education matter? Asia \& The Pacific Policy Studies 2017; 4(3): 586-601.

50. Zalilah MS, Khor GL. Indicators and nutritional outcomes of household food insecurity among a sample of rural Malaysian women. Pakistan Journal of Nutrition 2004; 3(1): 50-55.

51. Naser IA, Jalil R, Wan Muda WM, Wan Nik WS, Zalilah MS, Abdullah MR. Assessment of food insecurity and nutritional outcomes in Bachok, Kelantan. Journal of Nutrition \& Food Sciences 2015; 5(3): 373-392.

52. Zalilah MS, Khor GL. Household food insecurity and coping strategies in a poor rural community in Malaysia. Nutrition Research and Practice 2008; 2(1): 26-34.

53. Norhasmah S, Zalilah MS, Kandiah M, Mohd Nasir MT, Asnarulkhadi AS. Household food insecurity among urban welfare recipient households in Hulu Langat, Selangor. Pertanika Journal of Social Sciences \& Humanities 2012; 20(2): 405-420.

54. Law LS, Norhasmah S, Gan WY, Nur'Asyura AS, Nasir MTM. The identification of the factors 
related to household food insecurity among

indigenous people (Orang Asli) in Peninsular

Malaysia under traditional food systems. Nutri-

ents 2018; 10: 1455. 